\title{
Cell-wall polysaccharides play an important role in decay resistance of Sphagnum and actively depressed decomposition in vitro
}

\author{
Tomáš Hájek · Simon Ballance · Juul Limpens • \\ Mink Zijlstra $\cdot$ Jos T. A. Verhoeven
}

Received: 18 November 2009/Accepted: 29 March 2010/Published online: 11 April 2010

(C) The Author(s) 2010. This article is published with open access at Springerlink.com

\begin{abstract}
Sphagnum-dominated peatlands head the list of ecosystems with the largest known reservoirs of organic carbon (C). The bulk of this $\mathrm{C}$ is stored in decomposition-resistant litter of one bryophyte genus: Sphagnum. Understanding how Sphagnum litter chemistry controls $\mathrm{C}$ mineralization is essential for
\end{abstract}

T. Hájek ( $\square)$

Institute of Botany of ASCR, Dukelská 135,

37982 Třeboň, Czech Republic

e-mail: hajek@botany.cas.cz

T. Hájek

Faculty of Science, University of South Bohemia,

Branišovská 31, 37005 České Budějovice,

Czech Republic

S. Ballance

Norwegian Biopolymer Laboratory (NOBIPOL), Department of Biotechnology, Norwegian University of Science and Technology (NTNU), 7491 Trondheim, Norway

Present Address:

S. Ballance

Nofima mat AS, Osloveien 1, 1430 Ås, Norway

J. Limpens · M. Zijlstra

Nature Conservation and Plant Ecology Group, Wageningen University, Droevendaalsesteeg 3a, 6708 PB Wageningen, The Netherlands

\section{J. T. A. Verhoeven}

Landscape Ecology Group, Utrecht University, Prof. dr.

F.A.F.C. Wentgebouw, Sorbonnelaan 16, 3584 CA

Utrecht, The Netherlands understanding potential interactions between environmental changes and $\mathrm{C}$ mineralization in peatlands. We aimed to separate the effects of phenolics from structural polysaccharides on decay of Sphagnum. We measured aerobic microbial respiration of different moss litter types in a lab. We used chemical treatments to step-wise remove the chemical compounds thought to be important in decay-resistance in three taxonomically distant moss genera. We also focused on the effect of Sphagnum-specific cell-wall pectin-like polysaccharides (sphagnan) on $\mathrm{C}$ and $\mathrm{N}$ mineralization. Removing polymeric lignin-like phenolics had only negligible effects on C mineralization of Sphagnum litter, but increased mineralization of two other bryophyte genera, suggesting a minor role of these phenolics in decay resistance of Sphagnum but a major role of cell-wall polysaccharides. Carboxyl groups of pectin-like polysaccharides represented a C-source in non-Sphagnum litters but resisted decay in Sphagnum. Finally, isolated sphagnan did not serve as C-source but inhibited $\mathrm{C}$ and $\mathrm{N}$ mineralization instead, reminiscent of the effects reported for phenolics in other ecosystems. Our results emphasize the role of polysaccharides in resistance to, and active inhibition of, microbial mineralization in Sphagnum-dominated litter. As the polysaccharides displayed decay-inhibiting properties hitherto associated with phenolics (lignin, polyphenols), it raises the question if polysaccharide-dominated litter also shares similar environmental controls on decomposition, such as temperature or nutrient and water availability. 
Keywords Environmental changes .

Litter chemistry · Metabolites · Mosses ·

Nitrogen mineralization · Peatlands ·

Phenolics · Sphagnan

\section{Introduction}

Sphagnum-dominated peatlands play an important role in the global carbon $(C)$ cycle. Peatlands in the Northern hemisphere store between 270 and $370 \mathrm{Pg} \mathrm{C}\left(1 \mathrm{Pg}=10^{15} \mathrm{~g}\right)$ as peat (Turunen et al. 2002), amounting to $34-46 \%$ of the $\mathrm{CO}_{2}$ currently held in the atmosphere (IPCC 2007). In addition this ecosystem sequesters about $12 \%$ of current human emissions (Clymo et al. 1998). Understanding the mechanisms responsible for the build up of the peat deposits is of utmost importance to predict the risk of destabilising this huge $\mathrm{C}$ store.

Up to $90 \mathrm{vol} \%$ of the peat in Sphagnum-dominated peatlands consists of litter of a single moss genus: Sphagnum (Kuhry 1997; Turetsky 2003). Sphagnum does not posses extraordinary high primary production but, because of a slow rate of decomposition, its litter accumulates as peat. The slow litter decomposition in peatlands is generally attributed to the synergic effects of environmental factors, such as acidic and nutrient-poor soil conditions above and anoxic conditions below the water table, and the chemical composition of the litter, particularly Sphagnum (Rydin and Jeglum 2006). Although the latter is generally accepted to be important (van Breemen 1995; Turetsky et al. 2008) there is much debate about which compounds exactly confer the high decay resistance of Sphagnum litter, which resembles the resistance of woody tissues (Moore and Basiliko 2006).

One train of thought emphasizes the importance of phenolic compounds in Sphagnum. The cell-wall surface of Sphagnum mosses is coated with amorphous phenolic polymers, structurally and functionally similar to lignin (phenylpropane-based), presumably forming a physical barrier against decomposition (Tsuneda et al. 2001). In turn, these lignin-like phenolics decompose into soluble monomers such as sphagnum acid (Rudolph and Samland 1985; Williams et al. 1998). Together with other low-molecularweight soluble phenolics excreted by living cells (Rasmussen et al. 1995), they are assumed to inhibit the activity of extracellular enzymes, particularly under anaerobic conditions (Verhoeven and Liefveld 1997; Freeman et al. 2001). Although there is correlative evidence between the content of soluble phenolics in Sphagnum litter and its aerobic C-mineralization rate (Bragazza et al. 2006), antimicrobial properties of the phenolics are debatable (cf., Mellegård et al. 2009).

Another train of thought focuses on the role of Sphagnum cell-wall polysaccharides. Resource partitioning into metabolic and structural carbohydrates was found to predict the rate of litter mineralization (Turetsky et al. 2008) suggesting a passive mechanism of resistance to decomposition. Moreover, there are also indications of inhibitory, active mechanisms. Cell-wall holocellulose of Sphagnum mosses contains pectin-like rhamnogalacturonan I type polysaccharides (Ballance et al. 2007) together with xyloglucomannan and cellulose (Painter and Sørensen 1978; Painter 1983). Fragments of these pectin-like polymers are slowly released into the environment as so called sphagnan when the cell wall undergoes autogenic acid hydrolysis (Painter 1991). Uronic acids contained in the free or cell-wall bound sphagnan may either directly or indirectly inhibit microbial activity (Stalheim et al. 2009). Besides lowering $\mathrm{pH}$, the direct effect may involve interaction between dissociated carboxyl groups of sphagnan and the free amino groups of extracellular enzymes, rendering the enzymes ineffective by forming a polyelectrolyte complex. This process occurs in solutions of low ionic strength between $\mathrm{pH} 2.0$ and 4.8 (Ballance et al. 2008), i.e., conditions similar to bog water and may lead not only to limitation of $\mathrm{C}$ but also $\mathrm{N}$ mineralization, thus indirectly inhibiting microbial growth. The significance of such electrostatic (ionic) reactions in more complex natural environments has not yet been investigated. Earlier experiments (Painter 1991; Børsheim et al. 2001) suggesting irreversible condensation of amino groups by carbonyl groups contained in sphagnan, were not supported by later work (Ballance et al. 2008).

While soluble and polymeric phenolics are widespread in plant tissues and their inhibitory effect on microbial communities is generally known (Berg and McClaugherty 2008 but cf. Mellegård et al. 2009), the role of polysaccharides as inhibitors of decomposition processes has not been studied. In this paper, we attempted to differentiate the effects of lignin-like 
polymeric phenolics from the effect of free and bound sphagnan on decay of Sphagnum litter. We hypothesize that free and bound sphagnan provide Sphagnum with unique properties among mosses in inhibition of microbial litter mineralization. To test our hypothesis, we designed four experiments in which we measured aerobic microbial respiration of different moss litter types in a lab environment. For the first three experiments we used chemical treatments to step-wise remove or de-activate the chemical compounds thought to be important in decay resistance in three taxonomically distant moss genera. This approach allowed us to systematically separate the influence of the different compounds. The first experiment tested the hypothesis that the low litter respiration rate of Sphagnum mosses in relation to other mosses is a result of its cell-wall polysaccharides, not of lignin-like phenolics. The second and third experiments focussed more on the relative importance of the mechanisms by which polysaccharides might affect C-mineralization in Sphagnum and non-Sphagnum litters, such as the role of carboxyl groups and environment in the form of $\mathrm{pH}$. The fourth experiment took another approach. Here we applied isolated sphagnan to standardized Sphagnum-free plant litter to test the hypothesis that sphagnan inhibits microbial activity and thus $\mathrm{C}$ and $\mathrm{N}$ mineralization.

\section{Materials and methods}

\section{Origin of litters}

For experiments 1-3, we collected litter of four moss species, Sphagnum magellanicum, Sphagnum majus, Leucobryum glaucum and Polytrichum strictum. The moss litter was defined as recently dead (brown), usually $2 \mathrm{~cm}$ long shoot segments, which did not show signs of structural breakdown due to decomposition. S. magellanicum, S. majus and P. strictum were collected in a mountain ombrotrophic bog Rokytecká slať, Šumava National Park and Biosphere Reserve, Czech Republic $\left(49^{\circ} 1^{\prime} \mathrm{N}, 1^{\circ} 25^{\prime} \mathrm{E}\right)$. $S$. magellanicum dominated in drier habitats such as lawns and low hummocks while $S$. majus occupied exclusively wet carpets. P. strictum dominated the highest hummocks, which were already too dry for any Sphagnum species. Leucobryum glaucum formed typical cushions in the understory of nutrient-poor Scotch pine forest near Třeboň, Třeboňsko Protected Landscape Area and Biosphere Reserve, Czech Republic $\left(48^{\circ} 59^{\prime} \mathrm{N}, 14^{\circ} 50^{\prime} \mathrm{E}\right)$. In the laboratory, we removed remaining living and decomposing tissues and other coarse plant remnants from the litter and washed all the litter with distilled water for about $15 \mathrm{~min}$ to remove fine debris. The litter was dried at $25^{\circ} \mathrm{C}$ and relative air humidity of $40 \%$. Before it was fully dry, it was briefly homogenized using a kitchen mixer to obtain particles $<5 \mathrm{~mm}$ long. This material, referred to as fresh litter, was poor in soluble phenolics $(<1.0 \mathrm{mg}$ of tannic acid standard per $\mathrm{g}$ of dry mass), as estimated using the Folin-Ciocalteu assay (Bärlocher and Graça 2005).

For experiment 4, recently senesced (brown) leaves of Eriophorum angustifolium were collected from Clara Bog, Ireland $\left(53^{\circ} 51^{\prime} \mathrm{N}, 6^{\circ} 27^{\prime} \mathrm{W}\right)$. We choose this litter type for its common occurrence in peatlands and its relatively high decay rate (Limpens and Berendse 2003), likely ensuring measurable effect sizes. The leaves were dried at $70^{\circ} \mathrm{C}$ and ground to approximately 2-mm fragments. C:N of 48 indicated nutrient-poor litter quality.

Microbial inoculum

We inoculated litters with a suspension of a natural microbial community. We made a leachate from S. magellanicum litter collected above the water table from a bog.

For experiments $1-3,1 \mathrm{~kg}$ of fresh litter was shaken in 31 of de-ionized water for $1 \mathrm{~h}$. The slurry was filtered through a fine polyamide mesh and coarse filter paper. Based on pre-experimental tests we added mineral nutrients to avoid nutrient limitation of microbial $\mathrm{C}$ mineralization rate (concentrations in $\mathrm{mg} \mathrm{l}^{-1}$ are parenthesized): $\mathrm{NH}_{4} \mathrm{Cl}$ (1000), $\mathrm{K}_{2} \mathrm{HPO}_{4}$ (1000), $\quad \mathrm{MgSO}_{4} \cdot 7 \mathrm{H}_{2} \mathrm{O}$ (200), $\mathrm{CaCl}_{2} \cdot 2 \mathrm{H}_{2} \mathrm{O}$ (20), $\mathrm{FeCl}_{3} \cdot 6 \mathrm{H}_{2} \mathrm{O}(10), \mathrm{MnSO}_{4} \cdot \mathrm{H}_{2} \mathrm{O}(4), \mathrm{CuSO}_{4} \cdot 5 \mathrm{H}_{2} \mathrm{O}$ (1). For experiment 2 , we used also doubled concentrations of salts of multivalent cations $\mathrm{Mg}^{2+}, \mathrm{Ca}^{2+}, \mathrm{Fe}^{3+}$, and $\mathrm{Mn}^{2+}$. The latter was done to avoid potential limitation of the decomposer community by essential metallic cations complexed preferably on carboxyl groups of the chlorite-treated then carboxyl-reduced litter (Thomas and Pearce 2004). The initial ionic strength of the inoculum was 31-35 mM, which is still favourable for sphagnan-protein complexation (Ballance et al. 2008). 
For experiment 4, the litter of $S$. magellanicum was inserted into tubes (each $5 \mathrm{~g}$ fresh-weight) together with $30 \mathrm{ml}$ of artificial rainwater (Garrels and Christ 1965) and 20 glass beads to facilitate dislodging of micro-organisms from the fibrous Sphagnum peat (Hopkins et al. 1991). The tubes were shaken at $5^{\circ} \mathrm{C}$ for $2 \mathrm{~h}$ and centrifuged at $500 \times g_{\mathrm{n}}$ for $2 \mathrm{~min}$ and the supernatant collected. This procedure was repeated two times after re-suspending the residue with fresh rain water. To concentrate the micro-organisms collected with the water (c. $1120 \mathrm{ml}$ in total), approximately half of the water was drained overnight using submerged Teflon-coated Rhizon soil moisture samplers (Eijkelkamp Agrisearch Equipment, Giesbeek, the Netherlands) at $5^{\circ} \mathrm{C}$.

\section{Experiment 1}

To separate the effects of cell-wall polysaccharides and phenolics on microbial respiration, litters of four moss species: S. magellanicum, S. majus, L. glaucum and $P$. strictum were subjected to three different chemical pre-treatments to selectively remove a number of compounds. This resulted in three litter forms: (i) fresh, i.e., untreated dried litter, (ii) chlorite-treated and (iii) borohydride-treated which was incubated for 64 days, during which respiration was followed. In total there were 4 species $\times 3$ treatments $\times 3$ replicates $=36$ samples. The $\mathrm{pH}$ was set to 3.5 in all samples using $\mathrm{HCl}$.

Chlorite treatment involved removing the majority of aromatic polymers bound in cell walls. To this end fresh litter was boiled with acetone:methanol $(2: 1 \mathrm{v} / \mathrm{v})$ for 6 times $5 \mathrm{~min}$ and bleached with sodium chlorite (Ballance et al. 2007). We thus obtained papery-white material which is assumed to be free of lignin-like phenolic polymers. This and subsequent treatments required careful manipulation with $L$. glaucum and particularly $P$. strictum because the bleached leaves became very fragile; Sphagnum structure was not noticeably affected. The C:N of fresh litter was about 65-90, and increased to about 110-270 after the chlorite treatment (lower values: $S$. magellanicum and $P$. strictum, higher values: $S$. majus and L. glaucum). We assume that adding $2.05 \mathrm{mg}$ of $\mathrm{NH}_{4}{ }^{+}-\mathrm{N}$ per tube minimized potential effects of the initial litter $\mathrm{N}$ content $(0.11-0.25 \mathrm{mg}$ of $\mathrm{N}$ per tube) on $\mathrm{C}$ mineralization.
The chlorite treatment is commonly used for holocellulose quantification in plant tissues. It removes most of the lignin and other phenolics, as analyzed by optical spectrometry and confirmed by pyrolysis mass spectrometry (Morrison and Mulder 1995), and has a low impact on carbohydrate composition (Reeves 1993).

For the borohydride treatment, chlorite-bleached litter was further treated with sodium borohydride in order to reduce any carbonyl groups according to the standard procedure described in Ballance et al. (2007). The final borohydride-treated litter is assumed to be free of carbonyl groups. The litter $\mathrm{C}: \mathrm{N}$ increased to $366-825$ after borohydride treatment.

About $70.0 \mathrm{mg}$ (oven-dry weight) of fresh or treated litter was inserted in 12-ml Exetainer glass tubes with screw septum cap. Samples were inoculated with $6 \mathrm{ml}$ of microbial inocula and tubes were placed into an incubator at $15^{\circ} \mathrm{C}$ and relative humidity (RH) of $>95 \%$ to minimize water evaporation from the uncapped tubes. $12 \mathrm{~h}$ prior to respiration measurements, the uncapped tubes were thoroughly vortexed, closed with a septum cap, and placed in the incubator horizontally to enhance gas exchange between the suspension and air. After the incubation period of $12 \mathrm{~h}$, the capped tubes were vortexed and a $200-\mu 1$ air sample was taken with a gas-tight syringe to analyze the $\mathrm{CO}_{2}$ concentration on an Agilent 6850 gas chromatograph (Agilent Technologies, USA). During the incubation period 1114 samplings were made; the $\mathrm{CO}_{2}$ production was measured every second day in the beginning up to about once per 12 days at the end. Samples were vortexed at least every 3rd day to avoid anoxic conditions.

Measured $\mathrm{CO}_{2}$ concentrations were converted to $\mathrm{CO}_{2}$ production per initial $\mathrm{C}$ content per hour and these values were integrated in cumulative $\mathrm{C}$ loss for the whole 64-day period of the experiment. After the last measurement (64 days), the samples were lyophilized and weighted to obtain actual $\mathrm{C}$ loss. As the starting $\mathrm{CO}_{2}$ concentration in the tubes was not measured directly after capping, this cumulative $\mathrm{C}$ loss is an overestimation of the actual C loss and needed to be proportionally adjusted based on the actual C loss (using Goal Seek function in MS Excel). Changes in relative $\mathrm{C}$ content of the samples during incubation were neglected in the calculations. 
Experiment 2

To estimate the effect of cell-wall carboxyls on microbial respiration, the litters of two moss species, $S$. magellanicum and L. glaucum, were subjected to two chemical pre-treatments: (i) chlorite-treatment and (ii) carboxyl-reduction, amended with two concentrations of divalent metal ions (standard and doubled) in the inoculum, and incubated for 69 days during which respiration was followed. In total there were 2 species $\times 4$ treatments $\times 3$ replicates $=24$ samples. $\mathrm{pH}$ was set to 3.5 in all samples using $\mathrm{HCl}$.

Doubling the concentration of divalent cations did not affect $\mathrm{C}$ mineralization (Table 2), suggesting that the microbial community was not limited by availability of essential divalent cations and that the addition of cations (ionic strength of $4 \mathrm{mM}$ ) did not affect potential electrostatic interactions between litter carboxyls and microbial enzymes.

For details on chlorite treatment see experiment 1. Carboxyl-reduction involved the following procedure. We adapted the method based on the reduction of the carbodiimide-activated carboxyls (Stenutz et al. 2004). $1.2 \mathrm{~g}$ of chlorite-treated litter were suspended in $250 \mathrm{ml}$ of water in a 2-1 bottle and $50 \mathrm{ml}$ of $0.2 \mathrm{M}$ 2-(4-Morpholino-) ethanesulfonic acid, $\mathrm{pH} 4.75$, were added, followed by $12 \mathrm{~g}$ of new $\mathrm{N}$-(3-Dimethylaminopropyl)-N'-ethylcarbodiimide hydrochloride (carbodiimide). After $4 \mathrm{~h}$ of stirring at room temperature, $250 \mathrm{ml}$ of $2 \mathrm{M}$ TRIS $\mathrm{pH} 9$ were added and followed by a few drops of octanol to prevent foaming. After the sample had cooled in an ice bath, $250 \mathrm{ml}$ of $17.5 \mathrm{~g}$ of $\mathrm{NaBH}_{4}$ in $0.05 \mathrm{M}$ $\mathrm{NaOH}$ was added and the suspension was kept overnight at $4{ }^{\circ} \mathrm{C}$ and then slowly neutralized to $\mathrm{pH}$ 6 by addition of glacial acetic acid. Litter was collected by vacuum filtration, washed in $0.5 \mathrm{M} \mathrm{NaCl}$ and then in $20 \mathrm{mM} \mathrm{HCl}$ to convert the carboxyls into their $\mathrm{H}^{+}$form, washed in three changes of a large volume (8 1) of distilled water and once with acetone $(500 \mathrm{ml})$. Finally, the litter was dried at room temperature and ready for incubation which followed the same procedure as for experiment 1 .

To test the effectiveness of our carboxyl-reduction treatment, we determined the uronic acid (UA) content before and after carboxyl reduction using the assay of Ahmed and Labavitch (1978). Samples were mill-ground before analysis. The original contents of UA were 27.5 and $21.9 \%$ in S. magellanicum and L. glaucum, respectively. It was reduced about $40 \%$ in S. magellanicum and $70 \%$ in L. glaucum. The C:N of 66 (S. magellanicum) and 98 (L. glaucum) in carboxyl-reduced litter suggests that some carboxyls were successfully activated by carbodiimide but have not been reduced by borohydride, as indicated by the lower C:N and smaller carboxyl reduction in S. magellanicum.

\section{Experiment 3}

To evaluate the effect of $\mathrm{pH}$ on microbial respiration of cell-wall polysaccharides, chlorite-treated litter of two moss species, S. majus and L.glaucum, was incubated at three levels of $\mathrm{pH}(3.5,5.0$ and 6.5) for 68 days during which respiration was followed. In total there were 2 species $\times 3$ treatments $\times 3$ replicates $=18$ samples. The $\mathrm{pH}$ of the suspension was adjusted to $3.5,5.0$ or 6.5 by addition of either $\mathrm{HCl}$ or $\mathrm{NaOH} 6 \mathrm{~h}$ after inoculation and readjusted every 3-10 days. After each $\mathrm{pH}$ adjustment, a minimum calculated amount of $\mathrm{NaCl}$ was added to the samples to ensure equal ionic strength of the solution among all samples (up to $15 \mathrm{mM}$ of $\mathrm{Na}^{+}$). About $50 \%$ of carboxyls are dissociated at $\mathrm{pH} 3.5$ and about $97 \%$ at pH 5.0.

For details on the chlorite treatment or respiration measurements, see experiment 1 .

\section{Experiment 4}

To elucidate the effect of free soluble sphagnan on microbial respiration, Eriophorum angustifolium litter was amended with two polysaccharides: sphagnan (prepared from chlorite-treated litter of $S$. papillosum after Ballance et al. 2008) and polygalacturonic acid (PGA, Sigma P-3850, 79\% of galacturonic acid) in five concentrations $\left(0,5,10,20\right.$, and $50 \mathrm{mg} \mathrm{g}^{-1} \mathrm{l}$; dry weight equivalent) and incubated for 30 days. Sphagnan and PGA were added in the same concentrations, as both compounds have a similar C-content per monomer. In total there were: 10 treatments $\times 3$ replicates $=30$ samples. After the incubation cumulative $\mathrm{C}$ mineralization and changes in dissolved inorganic (DIN) and organic nitrogen (DON) fractions were measured.

The ground litter of E. angustifolium was mixed with quartz sand (Merck) and inoculum in a weightratio of 1:3:5. This ratio was found to be optimal for 
microbial respiration in a previously conducted pilot experiment. The substrate was then covered and preincubated at $20^{\circ} \mathrm{C}$ for 1 week, during which the microbial community could build up and stabilize (Kraus et al. 2004). Hereafter the substrate was mixed thoroughly and portions of $15 \mathrm{~g}$ were divided over 35 plastic containers $(4.5 \mathrm{~cm}$ in diameter, height of $5.0 \mathrm{~cm}$ ). Five containers with substrate were kept apart for chemical analyses. To compensate for the $\mathrm{N}$ lost during the pre-incubation period, $0.23 \mathrm{mg}$ of $\mathrm{N}$ was added as $\mathrm{NH}_{4} \mathrm{NO}_{3}$ to each of 30 containers. The added amount was based on the loss of mineral $\mathrm{N}$ during the pre-incubation period of the pilot experiment. After this, freshly prepared solutions of sphagnan or PGA ( $\mathrm{pH} 4.0$, adjusted with $0.1 \mathrm{M}$ $\mathrm{NaOH}$ ) were mixed through the substrates, and the whole containers were placed in 0.51 airtight mason jars and fitted with a septum-covered outlet. A thin layer of de-ionized water was added to the jars to keep RH constant. The jars were placed in an incubator under $20^{\circ} \mathrm{C}$ for 30 days.

It was not possible to completely dissolve PGA to prepare a $50 \mathrm{mg} \mathrm{g}^{-1}$ solution so this treatment was omitted from the experiment. The $\mathrm{pH}(\mathrm{KCl})$ at the end of the experiment ranged between 3.7 for the lowest concentration and 4.3 or 4.2 for the highest concentrations of sphagnan or PGA.

\section{Chemical analyses}

The initial $\mathrm{C}$ and $\mathrm{N}$ content of all the moss species and their litter forms (experiment 1-3) was determined by an Elemental analyzer (ThermoQuest Italia, Milan, Italy) in two replicates (coefficient of variation $<8 \%$ ). To be aware of possible $\mathrm{N}$-limitation of $\mathrm{C}$ mineralization in experiments 2 and 3 , we centrifuged the tubes at $5000 \times g_{\mathrm{n}}$ for $10 \mathrm{~min}$ at the end of incubation and used flow injection analysis to determine the concentration of available $\mathrm{NH}_{4}{ }^{+}$and $\mathrm{NO}_{3}{ }^{-}$ in the supernatant. The concentration of $\mathrm{NO}_{3}{ }^{-}$was negligible in all samples so $\mathrm{NH}_{4}{ }^{+}$represented the available DIN. No losses of DIN are expected through denitrification due to aerobic experimental conditions.

In experiment 4, we measured cumulative C mineralization as well as the changes in the DIN and DON. Soil samples were taken after pre-incubation before adding extra $\mathrm{N}$ (five containers), as well as at the end of the experiment (all containers). Prior to sampling, the substrate was mixed thoroughly in the containers and sub-samples were taken to determine water and ash contents, $\mathrm{C}: \mathrm{N}$, total dissolved nitrogen (TDN), nitrate nitrogen $\left(\mathrm{N}-\mathrm{NO}_{3}\right)$ and ammonium nitrogen $\left(\mathrm{N}-\mathrm{NH}_{4}\right)$. Water content was determined after drying at $105^{\circ} \mathrm{C}$ and ash content by ignition at $550^{\circ} \mathrm{C}$. The substrate was ground in a ballmill and its $\mathrm{C}$ content was determined on an elemental analyzer (Fisons Instruments EA 1108, Milan Italy). To determine the available $\mathrm{N}$ fractions, $8 \mathrm{~g}$ of fresh substrate was extracted with $20 \mathrm{ml} 1 \mathrm{M}$ $\mathrm{KCl}$ by shaking for $2 \mathrm{~h}$. $\mathrm{N}-\mathrm{NO}_{3}$, and $\mathrm{N}-\mathrm{NH}_{4}$ were measured colorimetrically using a continuous flow analyser (SKALAR SAN plus system, the Netherlands). TDN was measured as $\mathrm{N}-\mathrm{NH}_{4}$ after Kjeldahl digestion.

We express $\mathrm{C}$ loss per initial $\mathrm{C}$ content in \%. The amount of extra $\mathrm{C}$ added to the substrate as sphagnan or PGA was included in these calculations. DIN represents the sum of $\mathrm{N}-\mathrm{NO}_{3}$ and $\mathrm{N}-\mathrm{NH}_{4}$ contents, $\mathrm{DON}=\mathrm{TDN}-\mathrm{DIN}$.

\section{Statistical analyses}

Factorial general linear models (GLM) ANOVA were used to test effects of factors (species, treatment) on cumulative respiration at the end of incubation periods (experiments 2-3). Repeated measures (RM) GLM ANOVA was used to test factor effects on the course of respiration rates during incubation periods for all experiments. We employed nested design in case of experiment 1 to test the effect of groups (Sphagnum and non-Sphagnum), which both include two different species. Differences between means within factors were determined with Tukey's honestly significant difference (HSD).

In experiment 4 , the highest sphagnan concentration (50 $\mathrm{mg} \mathrm{g}^{-1}$ in which PGA did not dissolve) was not included in the RM ANOVA to keep the design balanced. The effect of adding the highest concentration of sphagnan was tested against the lowest concentration (no sphagnan added) using a two-tailed Student's $t$-test. The effect of C-mineralization rate on TDN and DIN was tested with an ANCOVA with substance as factor and concentration and C-mineralization as co-variables. C-mineralization rate had no effect on either TDN, DIN or DIN:DON ratio.

We used STATISTICA v. 8.0 software package. Statements given in Result section represent 
statistically significant differences $(\alpha=0.05)$ unless otherwise indicated.

\section{Results}

Experiment 1: mineralization of fresh, chloritetreated and borohydride-treated litter

Cumulative $\mathrm{C}$ mineralization (Fig. 1a) of fresh litter was similar in all species, ranging between 12 and $15 \%$ of the initial $\mathrm{C}$ concentration. Removing phenolics by chlorite treatment more than doubled $\mathrm{C}$ mineralization of non-Sphagnum species, whereas $\mathrm{C}$ mineralization of Sphagnum was hardly affected at all, leading to a strong litter $\times$ group interaction (Tab. 1). The above illustrates a key role for phenolic compounds as drivers of C-mineralization in Leucobryum and Polytrichum litter, but only a minor role in aerobic C mineralization of Sphagnum. Reduction of carbonyl groups after the borohydride treatment affected only litter of $S$. magellanicum, in which the $\mathrm{C}$ mineralization increased by $4 \%$ (Fig. 1a).

The $\mathrm{C}$ mineralization rate of fresh litters (Fig. 2a) decreased steadily after peaking at about $225 \mu \mathrm{g} \mathrm{g}^{-1} \mathrm{~h}^{-1}$ between 4 th and 7 th day, reaching a rate of $50 \mu \mathrm{g} \mathrm{g}^{-1} \mathrm{~h}^{-1}$ at the end of the incubation period for all species. In contrast, $\mathrm{C}$ mineralization rate of chlorite- and borohydride-treated litters, (Fig. $2 \mathrm{~b}-\mathrm{c}$ ) reached a roughly constant rate of about $100 \mu \mathrm{g} \mathrm{g}^{-1} \mathrm{~h}^{-1}$ after 10 days in both Sphagnum species, but continued to increase in P. strictum and L. glaucum to $350 \mu \mathrm{g} \mathrm{g}^{-1} \mathrm{~h}^{-1}$ at the end of the experiment, leading to significant interactions of all factors with TIME (Table 1).

Experiment 2: mineralization of carboxyl-reduced litter

Cumulative C mineralization (Fig. 1b) of chloritetreated litter of S. magellanicum was about 3.4 times lower than that of L. glaucum, and showed contrasting responses to carboxyl reduction between species (Table 2). While cumulative $\mathrm{C}$ mineralization increased by $4 \%$ in S. magellanicum it showed a similar decrease in L. glaucum, indicating that carboxyls represented a $\mathrm{C}$ source in the latter species.

The $\mathrm{C}$ mineralization rate of the carboxyl-reduced litter of S. magellanicum was far slower than in the
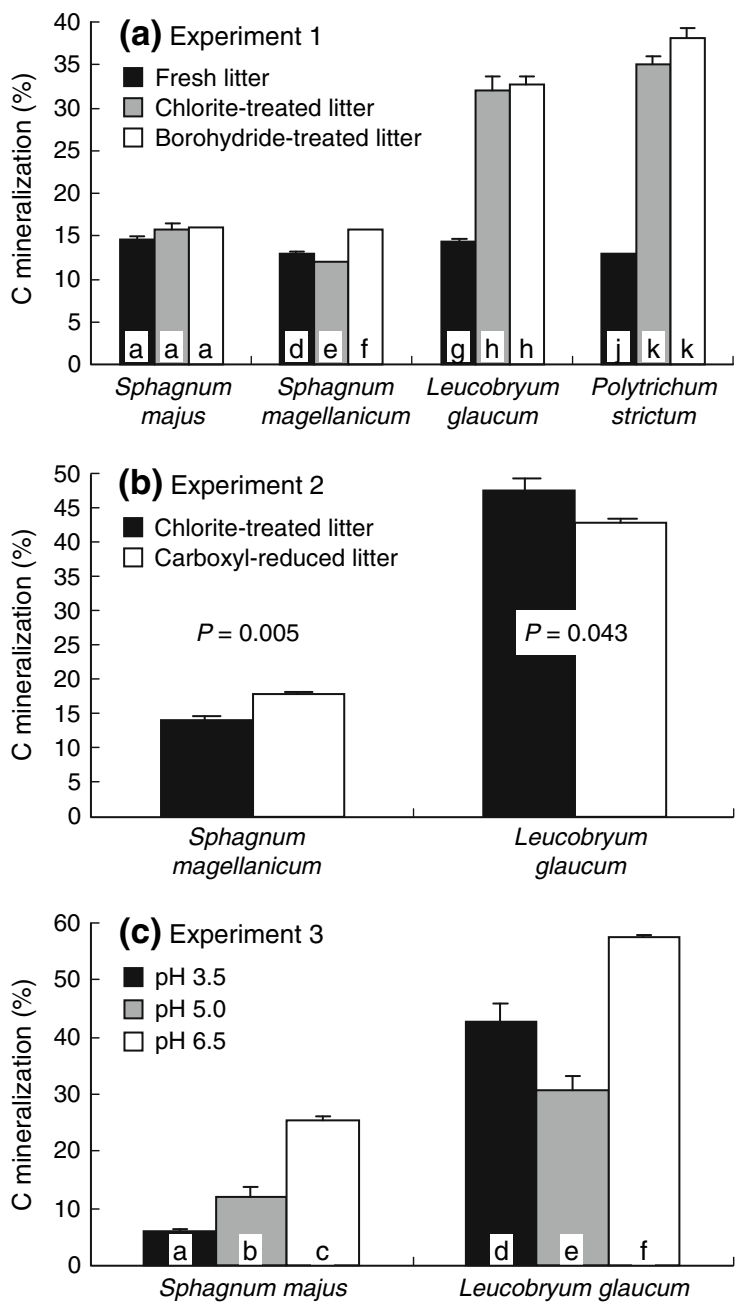

Fig. 1 Cumulative C mineralization (means + SE, $n=3$ ) in modified moss litters after 64-69 days of incubation. The chlorite-treated litter is assumed to be free of phenolics, represented particularly by lignin-like polymers. The borohydride-treated litter is, in addition, free of carbonyls. The carboxyl content of carboxyl-reduced litter was reduced about $40 \%$ in S. magellanicum and $70 \%$ in L. glaucum in comparison with the chlorite-treated control. Different letters indicate significant differences between litter forms within species ( $P<0.05$; one-way ANOVA, Tukey's HSD test), $P$ values refers to Student's $t$-test

original chlorite-treated litter during the initial 4 days (Fig. 3a). While the rate of $\mathrm{C}$ mineralization remained more or less stable during the 69-day period in S. magellanicum, it started to increase after about 30 days in L. glaucum. As a result the interactions of the repeated-measures factor TIME are statistically significant (Table 2). 


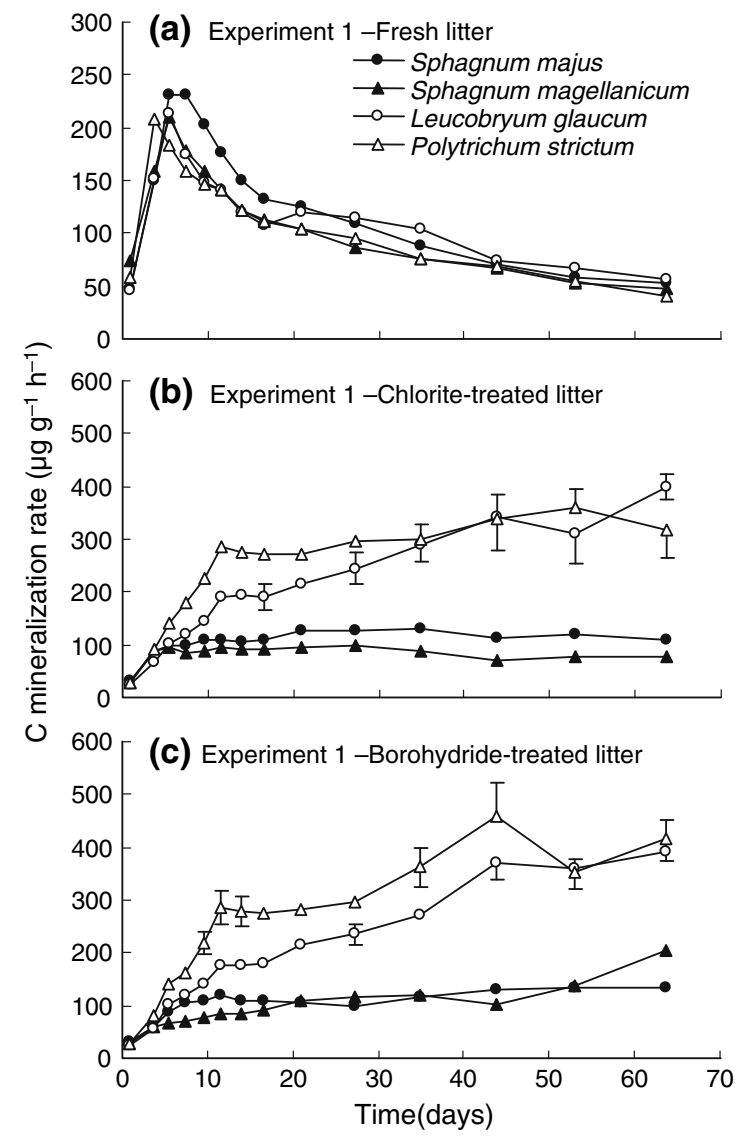

Fig. 2 The course of $\mathrm{C}$ mineralization rates in modified moss litters. The chlorite-treated litter is assumed to be free of particularly polymeric phenolics and the borohydride-treated litter, in addition, free of carbonyls. Means $\pm \operatorname{SE}(n=3)$; for readability, only relatively large SE values are shown. Note the different $y$-axis scales

Experiment 3: pH effect on $\mathrm{C}$ mineralization

The response of cumulative $\mathrm{C}$ mineralization to $\mathrm{pH}$ differed between species. It increased with increasing $\mathrm{pH}$ in chlorite-treated litter of $S$. majus. In $L$. glaucum, however, $\mathrm{C}$ mineralization was lowest at an intermediate $\mathrm{pH}$ of 5.0 and highest under the highest $\mathrm{pH}$ level of 6.5 (Figs. 1c and 3b). As a result the species $\times \mathrm{pH}$ interaction was statistically significant (Table 3), indicating that acidity alone was not the only factor suppressing microbial activity with decreasing $\mathrm{pH}$. The rate of $\mathrm{C}$ mineralization of L. glaucum at $\mathrm{pH}$ of 6.5 decreased in the last phase of the experiment (Fig. 3b), probably because of the exhausted content of available $\mathrm{NH}_{4}{ }^{+}$that fell below
$0.7 \mathrm{mM}$. In the other samples, $\mathrm{NH}_{4}{ }^{+}$ranged between 5.9 and $12.5 \mathrm{mM}$ (data not shown).

Experiment 4: effects of sphagnan and PGA addition on litter mineralization

Carbon mineralization responded differently to adding sphagnan and PGA, and was lowest for the sphagnan treatment (Fig. 4a, Table 4). Carbon mineralization remained unaffected by sphagnan addition up to $20 \mathrm{mg} \mathrm{g}^{-1}$, but it was depressed by adding $50 \mathrm{mg} \mathrm{g}^{-1}$. In contrast, $\mathrm{C}$ mineralization increased by adding 10 and $20 \mathrm{mg} \mathrm{g}^{-1}$ of PGA. The increase was such that it could not be explained by mineralisation of the added substrate alone, thus indicating increased decomposition of the plant litter, and a priming effect of PGA. The availability of nitrogen, expressed as total dissolved $\mathrm{N}$ (TDN) decreased from the initial $51 \mu \mathrm{g} \mathrm{N} \mathrm{g}^{-1}$ to below $30 \mu \mathrm{g} \mathrm{N} \mathrm{g}^{-1}$ at the end of the experiment for all treatments (Fig. 4c, Table 4). Thus, $\mathrm{N}$ uptake apparently exceeded mineralization indicating $\mathrm{N}$ co-limitation of the decomposer community. At the end of the experiment the TDN was positively related with sphagnan addition, while only the maximum PGA addition of $20 \mathrm{mg} \mathrm{g}^{-1}$ was followed by TDN increase (Fig. 4c). The concentration of dissolved inorganic $\mathrm{N}$ (DIN) decreased sharply from $23 \mu \mathrm{g} \mathrm{N} \mathrm{g}^{-1}$ to below $3 \mu \mathrm{g} \mathrm{g}^{-1}$ during the experiment for both treatments (Fig. 4b), especially the concentration of nitrate which reached values below the detection limit $\left(0.01 \mu \mathrm{g} \mathrm{g}^{-1}\right)$ at the end of the experiment. Despite this strong decline, there was still a treatment effect at the end of the experiment (Fig. 4b, Table 4). DIN concentration was lowest for the sphagnan treatment, indicating either a faster microbial uptake of DIN and/or lower $\mathrm{N}$ mineralization rate than in the PGA treatment. The addition of sphagnan and PGA had contrasting effects on the DIN concentrations: the more sphagnan added, the lower the DIN concentration, whereas the higher PGA addition, the higher the DIN concentration. In contrast with DIN, the concentration of dissolved organic $\mathrm{N}(\mathrm{DON})$ increased during the experiment in both treatments, particularly in sphagnan treatment (data not shown). As a result, the ratio between DIN and DON decreased from 0.8 to 0.2 and 0.1 for sphagnan and PGA, respectively, over the experimental period. At the end of the experiment, the ratio between DIN and DON differed between the 
Table 1 Experiment 1: the effects of moss group (Sphagnum and non-Sphagnum mosses), species (Sphagnum magellanicum and S. majus; Leucobryum glaucum and Polytrichum strictum), litter form (fresh, chlorite-treated, and borohydride-treated) on cumulative respiration at the end of the incubation period (nested ANOVA) and on the course of respiration rates during the incubation period (nested repeated measures ANOVA)

\begin{tabular}{|c|c|c|c|c|c|c|}
\hline \multirow[t]{2}{*}{ Source } & \multicolumn{3}{|c|}{ Cumulative respiration } & \multicolumn{3}{|c|}{ Respiration rates } \\
\hline & $F$ & d.f. & $P$ & $F$ & d.f. & $P$ \\
\hline Group & 237.5 & 1 & $<0.0001$ & 134.2 & 1 & $<0.0001$ \\
\hline Species (group) & 7.3 & 2 & 0.0028 & 13.9 & 2 & 0.0001 \\
\hline Litter & 159.1 & 2 & $<0.0001$ & 41.5 & 2 & $<0.0001$ \\
\hline Litter $\times$ group & 127.2 & 2 & $<0.0001$ & 96.4 & 2 & $<0.0001$ \\
\hline TIME [repeated measure factor] & & & & 10.4 & 13 & $<0.0001$ \\
\hline TIME $\times$ group & & & & 39.7 & 13 & $<0.0001$ \\
\hline TIME $\times$ species(group) & & & & 3.7 & 26 & $<0.0001$ \\
\hline TIME $\times$ litter & & & & 89.4 & 26 & $<0.0001$ \\
\hline TIME $\times$ litter $\times$ group & & & & 16.0 & 26 & $<0.0001$ \\
\hline
\end{tabular}

Table 2 Experiment 2: the effects of species (Sphagnum magellanicum and Leucobryum glaucum), litter form (chlorite-treated and carboxyl-reduced) and cations (normal and doubled concentration of divalent cations) on cumulative respiration at the end of the incubation period (ANOVA) and on the course of respiration rates during the incubation period (repeated measures ANOVA)

\begin{tabular}{|c|c|c|c|c|c|c|}
\hline \multirow[t]{2}{*}{ Source } & \multicolumn{3}{|c|}{ Cumulative respiration } & \multicolumn{3}{|c|}{ Respiration rates } \\
\hline & $F$ & d.f. & $P$ & $F$ & d.f. & $P$ \\
\hline Species & 2105.2 & 1 & $<0.0001$ & 1298.0 & 1 & $<0.0001$ \\
\hline Litter & 0.5 & 1 & 0.4855 & 28.4 & 1 & 0.0001 \\
\hline Cations & 0.0 & 1 & 0.8706 & 0.4 & 1 & 0.5616 \\
\hline Species $\times$ litter & 55.4 & 1 & $<0.0001$ & 33.4 & 1 & $<0.0001$ \\
\hline Species $\times$ cations & 0.2 & 1 & 0.6841 & 0.1 & 1 & 0.7531 \\
\hline Litter $\times$ cations & 0.0 & 1 & 0.9880 & 0.1 & 1 & 0.7238 \\
\hline Species $\times$ litter $\times$ cations & 0.4 & 1 & 0.5477 & 0.3 & 1 & 0.5934 \\
\hline TIME [repeated measures factor] & & & & 1030.4 & 11 & $<0.0001$ \\
\hline TIME $\times$ species & & & & 663.1 & 11 & $<0.0001$ \\
\hline TIME $\times$ litter & & & & 22.2 & 11 & $<0.0001$ \\
\hline TIME $\times$ cations & & & & 0.2 & 11 & 0.9976 \\
\hline TIME $\times$ species $\times$ litter & & & & 16.7 & 11 & $<0.0001$ \\
\hline TIME $\times$ species $\times$ cations & & & & 0.5 & 11 & 0.9203 \\
\hline TIME $\times$ litter $\times$ cations & & & & 0.1 & 11 & 0.9994 \\
\hline TIME $\times$ species $\times$ litter $\times$ cations & & & & 0.2 & 11 & 0.9991 \\
\hline
\end{tabular}

treatments, with the lowest DIN:DON ratio for the sphagnan treatment and the highest DIN:DON ratio for the PGA treatment (Fig. 4d, Table 4). Increasing additions of sphagnan and PGA seemed to have contrasting effects; sphagnan addition decreased DIN:DON ratio but PGA addition resulted in its increase.

\section{Discussion}

We showed that polymeric lignin-like phenolics play a minor role in maintaining the low aerobic C-mineralization rate of Sphagnum litter in the short term (10 weeks), but do play a role in other moss genera. We cannot exclude, however, that Sphagnum 


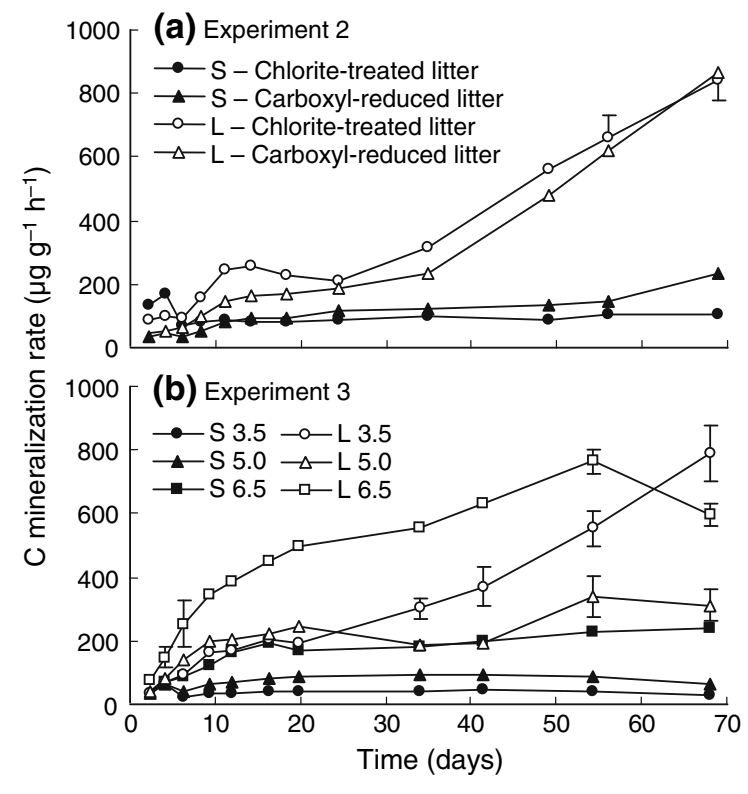

Fig. 3 The course of $\mathrm{C}$ mineralization rates in modified moss litters. S Sphagnum magellanicum, L Leucobryum glaucum; 3.5, 5.0 and 6.5 denote incubation $\mathrm{pH}$. The chlorite-treated litter is assumed to be free of particularly polymeric phenolics. The carboxyl content of carboxyl-reduced litter was reduced about $40 \%$ in S. magellanicum and $70 \%$ in L. glaucum in comparison with the chlorite-treated control. Means \pm SE $(n=3)$; for readability, only relatively large SE values are shown

phenolics in general, may indirectly limit aerobic C mineralization in bogs via nutrient limitation. That is, soluble phenolics, either those excreted by living Sphagnum or the lignin-like polymers that decompose into monomers, participate in formation of humic substances. This process is accompanied by

Table 3 Experiment 3: the effects of species (Sphagnum majus and Leucobryum glaucum) and $\mathrm{pH}$ (3.5, 5.0 and 6.5) on cumulative respiration at the end of the incubation period organic $\mathrm{N}$ and potentially $\mathrm{P}$ sequestration (Paludan and Jensen 1995) that may further intensify nutrient limitation already induced by the ombrotrophic character of the bog habitat. In other moss genera, such as Leucobryum and Polytrichum, phenolic polymers seem to form essential physical protection of polysaccharides against mineralization. For Sphagnum this mechanism seems to play a minor role towards the later phases of incubation (Fig. 2).

In accordance with our hypothesis, experiment 1 illustrated the importance of cell-wall polysaccharides in explaining the overall low $\mathrm{C}$ mineralization rate of Sphagnum litter relative to other moss litters (Lang et al. 2009). Whether differences in polysaccharide concentration also explain inter-specific differences in decay rate within Sphagnum, remains to be seen, although recent work (Turetsky et al. 2008) indicates that the ratio between easily and poorly degradable polysaccharide fractions is a good predictor for decay rates of Sphagnum species.

The negligible effect of carbonyl groups on $\mathrm{C}$ mineralization is consistent with recent works of Ballance et al. (2007, 2008) and Kristiansen et al. (2009) who did not find any evidence for abnormally large numbers of reactive carbonyls in Sphagnum cell-wall polysaccharides. Thus, the mechanisms, by which polysaccharides impede litter respiration, remain elusive. Interestingly, the proposed mechanisms so far show many similarities with those reported for phenolic compounds (Berg and McClaugherty 2008): sphagnan seems to be relatively stable in the environment (Painter 1991) and actively interferes with decomposers either directly or

(ANOVA) and on the course of respiration rates during the incubation period (repeated measures ANOVA)

\begin{tabular}{|c|c|c|c|c|c|c|}
\hline \multirow[t]{2}{*}{ Source } & \multicolumn{3}{|c|}{ Cumulative respiration } & \multicolumn{3}{|c|}{ Respiration rates } \\
\hline & $F$ & d.f. & $P$ & $F$ & d.f. & $P$ \\
\hline Species & 407.6 & 1 & $<0.0001$ & 314.1 & 1 & $<0.0001$ \\
\hline $\mathrm{pH}$ & 73.9 & 2 & $<0.0001$ & 69.4 & 2 & $<0.0001$ \\
\hline Species $\times \mathrm{pH}$ & 14.3 & 2 & 0.0007 & 13.8 & 2 & 0.0008 \\
\hline TIME [repeated measures factor] & & & & 106.5 & 10 & $<0.0001$ \\
\hline TIME $\times$ species & & & & 69.8 & 10 & $<0.0001$ \\
\hline TIME $\times \mathrm{pH}$ & & & & 4.0 & 20 & $<0.0001$ \\
\hline TIME $\times$ species $\times \mathrm{pH}$ & & & & 100.8 & 20 & $<0.0001$ \\
\hline
\end{tabular}



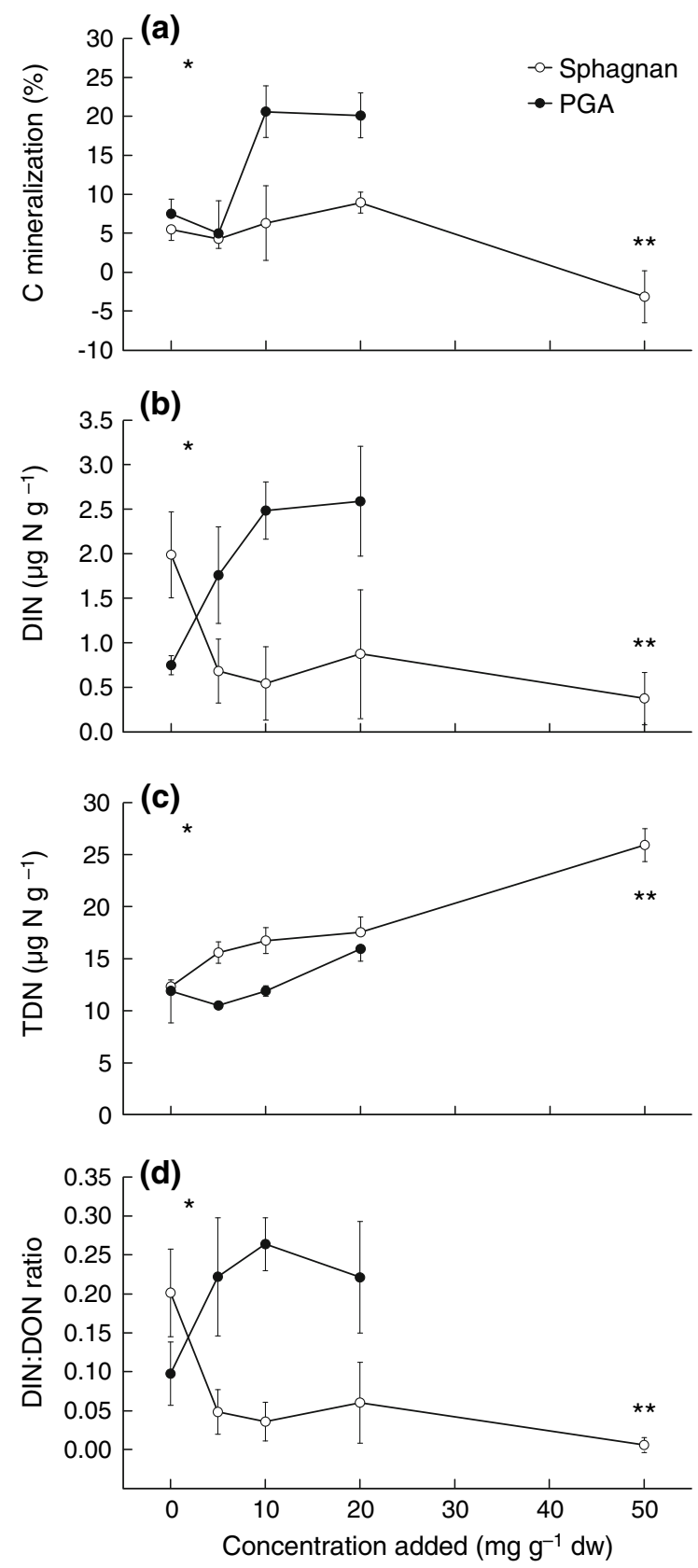

Fig. 4 Experiment 4. Effects of adding sphagnan and polygalacturonic acid (PGA) on a cumulative $\mathrm{C}$ mineralization of Eriophorum angustifolium leaf litter, b total dissolved $\mathrm{N}$ (TDN), $\mathbf{c}$ dissolved inorganic $\mathrm{N}$ (DIN), and $\mathbf{d}$ the ratio between DIN and dissolved organic N (DIN:DON). Error bars indicate $\pm \mathrm{SE} . *=$ significant difference between sphagnan and PGA treatment (repeated measures ANOVA over first four concentrations, see Table 1), ** significant difference between adding 0 (control) and $50 \mathrm{mg}$ sphagnan $\mathrm{g}^{-1}$ substrate (Student's t-test) indirectly through the $\mathrm{N}$-cycle and a decrease in DIN availability (experiment 4). In its cell-wall bound form, sphagnan is responsible for the high cation exchange capacity of Sphagnum that enables efficient nutrient acquisition under the extremely nutrient-poor and acidic environment of bogs (Clymo 1963; Hájek and Adamec 2009). Once released from the cell walls through autogenic acid-catalysed hydrolysis, sphagnan is stable (Painter 1991) and is not used as a C source (in contrast to PGA; experiment 4). Soluble sphagnan is a highly-branched macromolecule, its hairy appearance likely hampering easy access of hydrolysing enzymes. This recalcitrance of sphagnan is in contrast to non-branched de-esterified pectin chains, which generally undergo acid catalyzed hydrolysis easily (BeMiller 1986), as may be the case of the PGA used in our experiment 4 and of the lowered C-mineralization of L. glaucum after partial carboxyl reduction in experiment 2.

As stated in the introduction, sphagnan could affect the activity of the decomposer community by electrostatic immobilization of extracellular enzymes (Ballance et al. 2008) or lowering the $\mathrm{pH}$ (Stalheim et al. 2009). Ballance et al. (2008) studied interactions between isolated sphagnan and gelatine (a solubilised protein) at low ionic strength of $30 \mathrm{mM}$. Under low $\mathrm{pH}$ of about 2.0-4.8, sphagnan still had enough negative charge $(\mathrm{pK}=3.5)$ to bind the positively charged gelatine. This resulted in coacervation, i.e., colloidization of a sphagnan-gelatine complex. Although our experiments were not designed to directly test this mechanism, results of the experiment 4 do not argue against it: sphagnan addition of $50 \mathrm{mg} \mathrm{g}^{-1}$ resulted in DON accumulation (as exoenzyme immobilization), DIN shortage (due to lower $\mathrm{N}$ mineralization resulting from the immobilization) and the decrease of C-mineralization (due to $\mathrm{N}$ limitation and/or exoenzyme immobilization). Increased $\mathrm{pH}$ in experiment 3 was followed by increased C mineralization in Sphagnum but not completely in Leucobryum. Although increased $\mathrm{pH}$ would likely disable coacervation by decreasing the positive charge of proteins, our experiment does not allow us to separate between the coacervation effect and other $\mathrm{pH}$-related effects such as a shift towards the $\mathrm{pH}$ optimum of extracellular enzymes or towards a physiological optimum of the microbial community. 
Table 4 Experiment 4: ANOVA results for factorial effects of substance addition (sphagnan or PGA) and its concentration (0, 5, 10 and $20 \mathrm{mg} \mathrm{g}^{-1}$ ) on cumulative $\mathrm{C}$ mineralization, TDN, DIN, and DIN:DON

\begin{tabular}{|c|c|c|c|c|c|c|c|c|c|}
\hline \multirow[t]{2}{*}{ Source } & \multirow[t]{2}{*}{ d.f. } & \multicolumn{2}{|c|}{$\mathrm{C}$ mineralization } & \multicolumn{2}{|l|}{ TDN } & \multicolumn{2}{|l|}{ DIN } & \multicolumn{2}{|c|}{ DIN:DON } \\
\hline & & $F$ & $P$ & $F$ & $P$ & $F$ & $P$ & $F$ & $P$ \\
\hline Substance & 1 & 5.20 & 0.06 & 7.40 & 0.03 & 5.90 & 0.04 & 7.30 & 0.03 \\
\hline Concentration & 3 & 9.50 & $<0.01$ & 6.20 & $<0.01$ & 0.40 & 0.74 & 0.10 & 0.98 \\
\hline Substance $\times$ concentration & 3 & 4.90 & 0.01 & 2.10 & 0.12 & 4.50 & 0.01 & 4.00 & 0.08 \\
\hline
\end{tabular}

Perhaps the most intriguing result is that there are more biochemical alternatives in the plant world leading to slow litter decomposition. In some ecosystems, such as subtropical and forested peatlands, lignin-derived soil C dominates (Kuder et al. 1998; Williams et al. 1998; Jin et al. 2009), while in other ecosystems, such as Sphagnum-dominated bogs, polysaccharide-derived C prevails (Williams et al. 1998; Yavitt et al. 2005). But how can this result change our understanding of the environmental processes that control the rate of litter mineralization? Will the chemical composition and mineralization of polysaccharide-dominated litter respond differently from the lignin-rich litter to environmental changes, such as increased temperature, $\mathrm{CO}_{2}$ concentration, aerial $\mathrm{N}$ and $\mathrm{S}$ deposition or water deficiency? Although the answers to these questions merit further research, it is likely that the biggest difference would be the sensitivity of the decomposer activity after water table draw down. In phenolics-dominated litter the shut-down of phenol oxidase under anaerobic water-logged conditions is an important latch on C-mineralization (Freeman et al. 2001) which is far less effective in polysaccharide-dominated litter (Kuder and Kruge 2001).

Acknowledgments T. Hájek gratefully acknowledges the scientific and technical support of Luboš Adamec, Eva Kaštovská, Tomáš Picek and Hana Šantrůčková. This study was funded by the Research Project of the Academy of Sciences of the Czech Republic No. B600050503 and partly by Research Plans AV0Z60050516 and MSM6007665801. S. B. acknowledges the financial support of the Research Council of Norway through grant 173243 and the technical assistance of Ann Sissel Ulset.

Open Access This article is distributed under the terms of the Creative Commons Attribution Noncommercial License which permits any noncommercial use, distribution, and reproduction in any medium, provided the original author(s) and source are credited.

\section{References}

Ahmed AER, Labavitch JM (1978) A simplified method for accurate determination of cell wall uronide content. J Food Biochem 1:361-365

Ballance S, Børsheim KY, Inngjerdingen K, Paulsen BS, Christensen BE (2007) Partial characterisation and reexamination of polysaccharides released by mild acid hydrolysis from the chlorite-treated leaves of Sphagnum papillosum. Carbohyd Polym 67:104-115

Ballance S, Kristiansen KA, Holt J, Christensen BE (2008) Interactions of polysaccharides extracted by mild acid hydrolysis from the leaves of Sphagnum papillosum with either phenylhydrazine, $o$-phenylenediamine and its oxidation products or collagen. Carbohyd Polym 71:550-558

Bärlocher F, Graça MAS (2005) Total phenolics. In: Graça MAS, Bärlocher F, Gessner MO (eds) Methods to study litter decomposition: a practical guide. Springer, Dordrecht

BeMiller JN (1986) An introduction to pectins: structure and properties. In: Fishman ML, Jen JI (eds) Chemistry and function of pectins. American Chemical Society, Washington, DC

Berg B, McClaugherty C (2008) Plant litter: decomposition, humus formation, carbon sequestration, 2nd edn. Springer-Verlag, Berlin, Heidelberg

Børsheim KY, Painter TJ, Christensen BE (2001) Preservation of fish by embedment in Sphagnum moss, peat or holocellulose: experimental proof of the oxopolysaccharide nature of the preservative substance and of its antimicrobial and tanning action. Innov Food Sci Emerg Technol 2:63-74

Bragazza L, Freeman C, Jones T, Rydin H, Limpens J, Fenner N, Ellis T, Gerdol R, Hájek M, Hájek T, Iacumin P, Kutnar L, Tahvanainen T, Toberman H (2006) Atmospheric nitrogen deposition promotes carbon loss from peat bogs. PNAS 51:19386-19389

Clymo RS (1963) Ion exchange in Sphagnum and its relation to bog ecology. Ann Bot Lond 27:309-324

Clymo RS, Turunen J, Tolonen T (1998) Carbon accumulation in peat. Oikos 81:368-388

Freeman C, Ostle J, Kang H (2001) An enzymic latch on a global carbon store. Nature 409:149

Garrels RM, Christ CL (1965) Solutions, minerals and equilibria. Harper and Row, New York

Hájek T, Adamec L (2009) Mineral nutrient economy in competing species of Sphagnum mosses. Ecol Res 24:291-302 
Hopkins DW, MacNaughton SJ, O'Donnell AG (1991) A dispersion and differential centrifugation technique for representatively sampling microorganisms from soil. Soil Biol Biochem 23:217-225

IPCC (2007) Climate change 2007: the physical science basis. In: Solomon S, Qin D, Manning M, Chen Z, Marquis M, Averyt KB, Tignor M, Miller HL (eds) Contribution of working group I to the fourth assessment report of the intergovernmental panel on climate change. Cambridge University Press, Cambridge, New York

Jin Z, Shao S, Katsumata KS, Ishida T, Iiyama K (2009) Structural modification of lignin in peat during peat formation at tropical swamp. Japan Agr Res Quart 43:71-79

Kraus TEC, Zasoski RJ, Dahlgren RA, Horwath WR, Preston CM (2004) Carbon and nitrogen dynamics in a forest soil amended with purified tannins from different plant species. Soil Biol Biochem 36:309-321

Kristiansen KA, Ballance S, Potthast A, Christensen BE (2009) An evaluation of tritium and fluorescence labelling combined with multi-detector SEC for the detection of carbonyl groups in polysaccharides. Carbohyd Polym 76: 196-205

Kuder T, Kruge MA (2001) Carbon dynamics in peat bogs: Insights from substrate macromolecular chemistry. Global Biochem Cycles 15:721-727

Kuder T, Kruge MA, Shearer JC, Miller SL (1998) Environmental and botanical controls on peatification-a comparative study of two New Zealand restiad bogs using PyGC/MS, petrography and fungal analysis. Int J Coal Geol 37:3-27

Kuhry P (1997) The palaeoecology of treed bog in western boreal Canada: a study based on microfossils, macrofossils and physico-chemical properties. Rev Palaeobot Palyno 96:183-224

Lang SI, Cornelissen JHC, Klahn T, van Logtestijn RSP, Broekman R, Schweikert W, Aerts R (2009) An experimental comparison of chemical traits and litter decomposition rates in a diverse range of subarctic bryophyte, lichen and vascular plant species. J Ecol 97:886-900

Limpens J, Berendse F (2003) How litter quality affects mass loss and $\mathrm{N}$ loss from decomposing Sphagnum. Oikos 103:537-547

Mellegård H, Stalheim T, Hormazabal V, Granum PE, Hardy SP (2009) Antibacterial activity of sphagnum acid and other phenolic compounds found in Sphagnum papillosum against food-borne bacteria. Lett Appl Microbiol 49:8590

Moore TR, Basiliko N (2006) Decomposition. In: Vitt DH, Wieder RK (eds) Boreal peatland ecosystems. Ecological studies, vol 188. Springer-Verlag, Berlin, pp 126-143

Morrison IM, Mulder MM (1995) Pyrolysis mass spectrometry for the characterisation of straw and chemically treated straw. Phytochem Anal 6:74-84

Painter TJ (1983) Residues of D-lyxo-5-hexosulfopyranuronic acid in Sphagnum holocellulose, and their role in crosslinking. Carbohyd Res 124:C18-C21

Painter TJ (1991) Lindow man, Tollund man and other peatbog bodies - the preservative and anti-microbial action of sphagnan, a reactive glycuronoglycan with tanning and sequestering properties. Carbohyd Polym 15:123-142

Painter TJ, Sørensen NA (1978) The cation-exchanger of Sphagnum mosses: an unusual form of holocellulose. Carbohyd Res 66:C1-C3

Paludan C, Jensen HS (1995) Sequential extraction of phosphorus in freshwater wetland and lake sediment. Wetlands 15:365-373

Rasmussen S, Wolff C, Rudolph H (1995) Compartmentalization of phenolic constituents in Sphagnum. Phytochemistry 38:35-39

Reeves JB (1993) Chemical studies on the composition of fiber fractions and lignin determination residues. J Dairy Sci 76:120-128

Rudolph H, Samland J (1985) Occurrence and metabolism of sphagnum acid in the cell walls of bryophytes. Phytochemistry 24:745-749

Rydin H, Jeglum J (2006) The biology of peatlands. Oxford University Press, New York

Stalheim T, Ballance S, Christensen BE, Granum PE (2009) Sphagnan-a pectin-like polymer isolated from Sphagnum moss can inhibit the growth of some typical food spoilage and food poisoning bacteria by lowering the $\mathrm{pH}$. J Appl Microbiol 106:967-967

Stenutz R, Jansson E, Widmalm G (2004) A practical guide to structural analysis of carbohydrates. Methylation analysis with carboxyl reduction of the native polysaccharide. http://www.stenutz.eu/sop/sop6.html. Accessed Apr 2010

Thomas PA, Pearce DME (2004) Role of cation exchange in preventing the decay of anoxic deep bog peat. Soil Biol Biochem 36:23-32

Tsuneda A, Thormann MN, Currah RS (2001) Modes of cellwall degradation of Sphagnum fuscum by Acremonium cf. curvulum and Oidiodendron maius. Can J Bot 79:93-100

Turetsky M (2003) The role of bryophytes in carbon and nitrogen cycling. Bryologist 106:395-409

Turetsky R, Crow SE, Evans RJ, Vit DH, Wieder RK (2008) Trade-offs in resource allocation among moss species control decomposition in boreal peatlands. $\mathrm{J}$ Ecol 96:1297-1305

Turunen J, Tomppo E, Tolonen K, Reinikainen A (2002) Estimating carbon accumulation rates of undrained mires in Finland-application to boreal and subarctic regions. Holocene 12:69-80

van Breemen N (1995) How Sphagnum bogs down other plants. Trends Ecol Evol 10:270-275

Verhoeven JTA, Liefveld WM (1997) The ecological significance of organochemical compounds in Sphagnum. Act Bot Neerl 46:117-130

Williams CJ, Yavitt JB, Wieder RK, Cleavitt NL (1998) Cupric oxide oxidation products of northern peat and peat forming-plants. Can J Bot 76:51-62

Yavitt JB, Williams CJ, Wieder RK (2005) Soil chemistry versus environmental controls on production of $\mathrm{CH}_{4}$ and $\mathrm{CO}_{2}$ in northern peatlands. Eur J Soil Sci 56:169-178 